\title{
Koettu koulutustarve - näkökulmia ja kritiikkiä
}

\section{Taustaa}

Usein todetaan, että koulutustarve muodostaa aikuisten opetus-oppimisprosessin suunnittelun lähtökohdan. Näin epäilemättä on ja niinpä ei ole yllättävää, että koulutustarvetutkimuksia on viime aikoina tehty runsaasti. Tutkimuksien myötä on alan käsitteistö täsmentynyt ja yksinkertaistunut. Tämä ilmenee muun muassa siten, että lisääntyvässä määrin käytetään määrällisen koulutustarpeen sijasta nasevampia koulutusmäärien tai koulutusvirtojen käsitteitä ja yhä harvemmin vaivataan lukijaa subjektiivisen ja objektiivisen (kuvitellun ja luullun) koulutustarpeen käsitteillä.

Koulutustarpeen yksi keskeinen osa-alue on yksilön kokema koulutustarve (myöhemmin koettu koulutustarve). Käsitteinä koulutustarve ja erityisesti koettu koulutustarve ovat ongelmallisia: Yksilö pyrkii koulutuksen avulla lisäämään psyykkistä tai fyysistä hyvinvointiaan - harvemmin koulutus on itseisarvo sinänsä. Siten koulutustarvetta voi esiintyä ainoastaan siellä, missä koulutus (tai kasvatus) kykenee vaikuttamaan. Koettua koulutustarvetta voi kuitenkin esiintyä vaikka koulutus ei periaatteessa kykenisikään vaikuttamaan - tällöin yksilö odottaa koulutukselta liikaa. Yleisempi tilanne lienee kuitenkin se, että koulutus kykenisi vaikuttamaan yksilön psyykkiseen tai fyysiseen hyvinvointiin mutta hän ei syystä tai toisesta tiedosta koulutuksen vaikuttavuutta. Molemmat vaihtoehdot ovat aikuiskasvatuksen ja -koulutuksen kannalta ongelmallisia.

Tässä artikkelissa pyritään jäsentämään ja erittelemään niitä ennakko-oletuksia ja reunaehtoja, jotka nykyisellään sisältyvät koetun koulutustarpeen käsitteeseen ja tutkimusmetodologiaan. Tämä yritetään toteuttaa selvittelemällä tarveilmauksien, -lausumien ja koetun koulutustarpeen välisiä yhteyksiä. Lopuksi kritisoidaan vallitsevaa koetun koulutustarpeen määritelmää hyväosaisia suosivaksi ja esitetään niiden eräitä kehittämissuuntia, jotka mahdollisesti palvelisivat aiempaa paremmin yhtä aikuiskoulutuspolitiikan keskeistä tavoitetta - sivistyksellistä tasa-arvoa.

\section{Tarvelausumat ja koettu koulutustarve}

Koulutustarve ja koettu koulutustarve muodostuu tarveilmauksista. Yleensä ne esitetään kielellisesti, jolloin on luontevaa kutsua niitä tarvelausumiksi. Tarvelausuma edellyttää vallitsevan ja suotavan tilanteen vertailua. Tarvelausumassa ilmaistaan tarve (keino tai väline), jolla suotavampi tilanne kuvitellaan saavutettavan. Näin tarvelausuma ja siinä ilmaistu tarve muodostavat sillan vallitsevan ja suotavan tilanteen välille (Tuomisto 1981, 200).

Lause "haluan opiskella aikuiskasvatusta" on tarvelausuma, joka selkeästi ilmaisee myös koettua koulutustarvetta. Tarpeiden ja tarvelausumien luonnetta on ansiokkaasti käsitellyt Lawson (1975, 33-41). Hänen mukaansa tarvelausumat syntyvät seuraavasti:

1) Vallitsevassa tilanteessa esiintyy tai oletetaan esiintyvän puutteellisuuksia.

2) Puutteellisuuksien arviointi perustuu arvoihin ja normeihin, jotka määrittelevät suotavana pidetyn tilanteen.

3) Puutteellisuuden poistamiseksi laaditaan toimintasuunnitelma.

4) Toimintasuunnitelma muodostaa tarpeen ja se ilmaistaan tarvelausumina.

Tarvelausumat ja erityisesti koettua koulutustarvetta- kuvaavat tarvelausumat syntyvät siten monimutkaisen päättelyprosessin tulok- 
sena - siihen, mikä on tämän merkitys aikuiskoulutukselle, palaan tuonnempana.

Tarvelausumia voidaan siten pitää toimintasuunnitelmina, jotka perustuvat havaittuihin tai oletettuihin puutteellisuuksiin. Tarvelausumien, vallitsevan ja suotavan tilanteen yhteys on kuitenkin edelleen ongelmallinen. Tätä yritetään havainnollistaa seuraavalla tarvelausumien luokittelulla (Taylor 1959, 107-110). Tämän artikkelin kirjoittaja on itse nimennyt tarvelausumaluokat mahdollisimman kuvaaviksi aikuiskasvatuksen kannalta.

1. Ehdollinen ja informatiivinen tarvelausuma.

Tarvelausuma viittaa tulevaisuudessa mahdollisesti esiintyvään tilanteeseen. Siinä todetaan kyseisessä tilanteessa esiintyväksi tarve tai puutos. Tarvelausuman tarkoite on usein informatiivinen. Esimerkiksi "'jos minusta tulee aikuiskouluttaja, on minun jatkuvasti kehitettävä itseäni'”.

2. Instrumentaalinen tarvelausuma.

Tarvelausuma viittaa suoraan vallitsevan ja suotavamman tilanteen erotukseen. Tarve on suotavamman tilanteen todellistamisen väline ja tarvelausuma osoittaa tämän välineen. Esimerkiksi "ollakseni hyvä aikuiskouluttaja on minun jatkuvasti kehitettävä itseäni ja seurattava ajan tapahtumia".

3. Normatiivisesti suositteleva tarvelausuma.

Tarvelausuma on luonteeltaan suositteleva ja sillä viitataan yleisesti hyväksyttyyn päämäärään tai arvoon. Tällöin se on usein eettismoraalinen. Esimerkiksi "isänmaa tarvitsee työteliäitä aikuiskouluttajia"'.

4. Deskriptiivinen tarvelausuma.

Tarvelausumalla kuvataan vallitsevaa tilannetta. Psykologiassa tämä lausumatyyppi on yleinen. Esimerkiksi "'aikuiskouluttajien menestymisen tarve on suurempi kuin muilla ammattiryhmillä keskimäärin”.

Esitetyssä tarvelausumaluokittelussa voidaan kolmen ensimmäisen tarvelausumatyypin mielekkyys kyseenalaistaa monella tapaa:

1. Tarvelausuman ilmaisema päämäärä kyseenalaistetaan - miksi on tarpeen olla hyvä aikuiskasvattaja.

2. Tarvelausuman ilmaiseman tarpeen ja tarvetta vastaavan päämäärän yhteys kyseenalaistetaan - hyvän aikuiskouluttajan ei välttämättä tarvitse kehittää itseään.

3. Tarvelauseen ilmaiseman tarpeen esiintyminen kiistetään - aikuiskouluttajat kehittävät jo riittävästi itseään.

4. Päämäärän ja sitä vastaavan tarpeen nykyinen mielekkyys kyseenalaistetaan - on tär- keää, että aikuiskouluttajat kehittävät itseään mutta vielä tärkeämpää on, että he ovat omaksuneet aikuiskasvatuksen yleiset arvopäämäärät.

Tarvelausumat ovat siten monimuotoisia ja usealla eri tapaa kyseenalaistettavissa. Tällöin joutuu välittömästi kysymään, mitä koettu koulutustarve itse asiassa on, kuinka hyvin yksilö kykenee arvioimaan koulutustarpeensa ja kuinka paljon siitä voidaan tai halutaan ilmaista kielellisesti tarvelausumina: onko koettu koulutustarve määriteltävä Paukkua (1978, 37) soveltaen siten, että todellinen koettu koulutustarve on se hypoteettinen koulutustarve, jota käytännössä ei saada selville.

\section{Koetun koulutustarpeen käsitteen kritiikkiä ja kehittämissuuntia}

.'Elämästä viriää aikuisopiskelijan oppimisen mieli ja suunta" on aikuiskasvatuksessa usein toistettu fraasi. Koettu koulutustarve määritellään yleensä - tavalla tai toisella tiettyyn oppisisältöön, koulutusalaan tai muotoon kohdistetuksi kiinnostukseksi ja opiskeluhalukkuudeksi. Tämän kaltainen määritelmä edellyttää yksilöltä varsin vaativaa päättelyketjua: Hänen on kyettävä diagnostisoimaan itsensä ja elämäntodellisuutensa, mahdollisuutensa, rajoituksensa ja toivomansa muutoksen luonne. Näin yksilön oletetaan tiedostavan hyvin paljon ja vielä lisäksi kykenevän arvioimaan koulutusta yhtenä mahdollisena muutosstrategiana eli kykenevän koulutuksen vaikuttavuuden arviointiin - tehtävään, joka on haastava kasvatusalan tutkijallekin.

Toinen, edelliseen liittyvä, koetun koulutustarpeen käsitteen ja sen määritelmien ongelma on, että ne kattavat yleensä ainoastaan kiteytyneimmät ja selkeimmät koulutukseen kohdistuvat tarvelausumat. Kuitenkin sosiologisista ja sosiaalipoliittisista tutkimuksista tiedetään, että huonompiosaisuuden kehään kuuluu yleensä moniongelmainen elämäntilanne ja vähäinen tottumus todellisuuden kielelliseen jäsentämiseen. Tämä on yksi selitys siihen, miksi koettua koulutustarvetta ei esiinny siellä "'missä pitäisi": vallitseva koetun koulutustarpeen käsite ja tutkimusmetodologia suosii todellisuuden kielelliseen jäsentämiseen tottuneita ihmisiä - käytännössä pitkän ja monipuolisen koulutuksen saaneita. 
Koetun koulutustarpeen käsitettä, sen määrittelyä ja tutkimusmetodologiaa on kehitettävä. Koetun koulutustarpeen määrittelyssä lienee syytä pyrkiä vapautumaan turhan vaativista ennakko-oletuksista ja reunaehdoista - elämästä viriävän oppimisen mieli ja suunta ei aina kiteydy selkeiksi kielellisiksi tarvelausumiksi. Siten koetun koulutustarpeen käsitteellistämisessä on selkeiden koulutustarvelausumien lisäksi yritettävä tavoittaa myös diffuusit, monimerkitykselliset ja jopa ristiriitaiset koulutustarveilmaukset. Tämä edellyttää aiempaa tulkitsevampaa, dynaamisempaa ja innovatiivisempaa tutkimusotetta. Koetun koulutustarpeen tutkimuksessa antoisia suuntauksia saattavat näin olla esim. kehittävä toimintatutki- mus ja koulutustarpeen kartoitukseen soveltuvien projektiivisten tutkimusmenetelmien kehittely.

\section{Lähteet}

Lawson, K. 1975. Philosophical concepts and values in adult education. Nottingham: Barnes \& Humby.

Paukku, R. 1978. Yrityksen esimiestaidollisen koulutustarpeen mittaaminen. Tampereen yliopiston kasvatustieteen laitoksen julkaisuja A:14.

Taylor, P. 1959. Need statements. Analysis 18, 106-111.

Tuomisto, J. 1971. Koulutustarve elinikäisen kasvatuksen näkökulmasta. Alanen, A. \& Sihvonen, J. (toim.) Elinikäinen kasvatus. Porvoo: WSOY. 